OPEN ACCESS

Edited by:

Xiubin Lin,

Zhejiang University, China

Reviewed by:

Lin Wu,

Institute of Geomechanics, Chinese

Academy of Geological Sciences,

China

Luolei Zhang,

Tongji University, China

*Correspondence:

Xiaoying Zhu

2921860065@qq.com

Fangxin Ning

18810449167@sina.cn

Specialty section:

This article was submitted to Structural Geology and Tectonics, a section of the journal

Frontiers in Earth Science

Received: 30 November 2021

Accepted: 17 December 2021

Published: 18 January 2022

Citation:

Kuang X, Zhu X, Ning F, LiW, Zheng Q, Li B and Zhou D (2022) AeromagneticImaged Basement Fault Structure of the Eastern Tarim Basin and Its

Tectonic Implication.

Front. Earth Sci. 9:825498 doi: 10.3389/feart.2021.825498

\section{Aeromagnetic-Imaged Basement Fault Structure of the Eastern Tarim Basin and Its Tectonic Implication}

\author{
Xingtao Kuang, Xiaoying Zhu*, Fangxin Ning *, Wei Li, Qifang Zheng, Bing Li and \\ Daoqing Zhou
}

China Aero Geophysical Survey and Remote Sensing Center for Natural Resources, China Geological Survey, Beijing, China

The property of the magnetic basement and the faults in the basement is significant for structural evolution, the Phanerozoic deposition, and oil resource exploration of the Tarim Basin. Based on the newly acquired aeromagnetic and industry seismic data, we mapped the distribution of basement faults by applying magnetic gradient-processing methods such as the horizontal gradient derivative, the first vertical derivative, the tilt derivative, and the upward continuation method. The dips of basement faults were confirmed and the susceptibilities of basement blocks were obtained by forward modeling of five profiles using the constraint of sedimentary strata depth and Moho topography. On the basis of comprehensive analysis of the magnetic anomalies, the distribution and inclination of basement faults, and susceptibilities differentiation obtained by forward modeling and field measurement, the property of the basement faults and their implication were discussed and interpreted. Our results show that the origin of the Central Highly Magnetic Anomaly Belt is highly magnetic Archean metamorphic rocks. The weakly magnetic Southeastern Domain and highly magnetic Central Tadong Domain assembled along the Tadong South Fault during the Paleoproterozoic. The Paleozoic Cherchen Fault is just an interior fault in the weakly magnetic Southeastern Domain although it presents a large vertical fault displacement. Considering the prominent variation of strikes of the Tadong North Fault system, and the moderately magnetic anomalies in the Northeastern Mangal Domain corresponding to the center of Neoproterozoic deposition, it is likely that the basement of the Northeastern Mangal Domain modified by the Neoproterozoic rifting could be originally the same as the basement of Central Highly Magnetic Anomaly Belt.

Keywords: Eastern Tarim Basin, aeromagnetic, profile modeling, basement fault, Neoproterozoic rifting, Paleoproterozoic assembly

\section{INTRODUCTION}

The Tarim Basin is the largest basin in mainland China, and has a broad prospect for oil and gas exploration. The long geological evolution history of the Tarim Basin is very complicated, and different zones of the Tarim Basin have various structural deformation forms (He et al., 2016; Zhu et al., 2017; Jiang et al., 2018; Morin et al., 2018; Wu et al., 2018; Laborde et al., 2019), therefore, the Tarim Basin is an ideal region for research on plates convergence and breakup and interaction among them (Dayem et al., 2009; Craig et al., 2012; Calignano et al., 2015). The distribution of basement faults throughout the basin's geological evolutionary history widely controlled the activities of blocks 
(Xu et al., 2002; Ma et al., 2009; Lin et al., 2015). Based on previous researches (Kang, 2004; Xu et al., 2005; Cai, 2007; Wang et al., 2009; Pu et al., 2011), some conclusions can be summarized as below: early existing faults play an important role in controlling the later fault and structural deformation; magmatic rocks are mainly distributed along the basement faults; and the basement faults can be traced and identified by geophysical data and methods (Lin et al., 2015).

Although there have been a lot of studies on basement faults of the Tarim Basin, some unsolved problems still exist. Some researchers studied the basement faults by adopting only one kind of geophysical method, such as the gravimetric method (Xu et al., 2005; Hou and Yang, 2011), the aeromagnetic method (Xu et al., 2002; Yang et al., 2012), and the seismic profiles interpretation (He, 1995; Ji, 2008; Tang et al., 2012). However, the industry seismic data are unable to map the deep basement fault because of its signal attenuation, especially for high-angle faults; the gravity anomalies can be caused by all the substance below the subsurface, including the sedimentary cover, basement, and Moho, and it is extremely difficult to distinguish the anomalies caused by the basement from other factors. Indeed a researcher synthetically utilized gravimetric data, aeromagnetic data, and seismic profiles to identify basement faults (Lin et al., 2015), however the location and strike of basement faults and lineaments of aeromagnetic anomalies did not correspond with each other in his paper. The aeromagnetic method is the most practically useful method to identify basement faults because the sedimentary cover is usually nonmagnetic or weak magnetic, and the magnetic layer is restricted above the Curie depth. Another problem that is usually neglected is the rock physical property of the basement to which seismic data are not sensitive ( $\mathrm{Li}$ and Gao, 2010; Tong et al., 2010; Tong et al., 2012; Gao et al., 2013; Xu et al., 2013). Because the terrane activity style is closely related to the property of basement rock which can be indicated by susceptibilities, based on the recently aeromagnetic data measured in 2015-2016 and strata depth from industry seismic data, we conducted the forward modeling of rock susceptibilities and basement faults.

\section{GEOLOGICAL SETTING}

The Tarim Basin is located in the southern region of Xinjiang Uygur Autonomous Region, China, between Tianshan Mountains and Western Kunlun-Altun Mountains (Figure 1). The basin is a large marine-continental depositional compound basin after experiencing multistage tectonic activities (Xu et al., 2013; Wu et al., 2018; He et al., 2019; Xu et al., 2021). After the initial continental crustal evolution in the Archean, the Tarim Craton was developed during the Proterozoic and Paleozoic by the accretion of the Kunlun, Qaidam, Tarim block, and the Central/South Tian Shan block (Charvet et al., 2007; Lin et al., 2013; Zhang C.-L et al., 2013; Zhang P. Z et al., 2013; Li et al., 2018), and by the extensional activities from the Neoproterozoic to Ordovician (Dong et al., 2016; Zhu et al., 2017; Ren et al., 2018; Wu et al., 2018). A lot of important basement structures such as the Bachu, Tanan, Tazhong, Tadong, Tabei, Kalpin, and Kuruk
Tagh basement-cored uplifts were established during the late Proterozoic and the early Paleozoic (Gao and Fan, 2014; Tang et al., 2014; Lin et al., 2015; Liu et al., 2015; Zhu et al., 2017; Wu et al., 2018).

The beginning of sedimentary strata may be traced to the Late Paleozoic or the Neoproterozoic (Guo et al., 2015; Wu et al., 2018; $\mathrm{He}$ et al., 2019). According to the drilling and industry seismic data, the Eastern Tarim Basin deposited the marine Neoproterozoic, Cambrian, Ordovician, Silurian, Devonian, Carboniferous and the continental Jurassic, Cretaceous, and Cenozoic strata, but not Permian and Triassic strata (Zhang C.-L et al., 2013; Xu et al., 2014). The Eastern Tarim Basin can be divided into four main structural units: Kongquehe Slope (KS), Mangal Depression (MD), Tadong Uplift (TU), and Southeastern Depression (SD) (Figure 2).

\section{ROCK PROPERTIES}

The magnetic susceptibilities were derived from samples collected from the wells located in the Eastern Tarim Basin, and from the outcrops measured in 2015-2016 in Kuruktagh, Tianshan, Altun, and Kunlun Mountains which surround the Eastern Tarim Basin, and also from published literature (Xiong et al., 2016a). The measured magnetic susceptibilities of exposure strata in the Eastern Tarim Basin are displayed in Table $\mathbf{1 .}$

The main rock types of the Sinian to the Early Ordovician consist of limestone, dolomite, and sand-mudstone, while the main deposition during the Late Ordovician to the Cenozoic is sandstone, mudstone, and sand-mudstone. Here, it should be noted that the work area lacks the Permian and Triassic strata, and the Carboniferous stratum only developed in the western region of the survey region. The average susceptibility (AS) of Cenozoic, Mesozoic and Paleozoic are not larger than $50 \times 10^{-5}, 20 \times 10^{-5}$, and $40 \times 10^{-5}$ SI, respectively. Most common rock types in Proterozoic, including marble, schist, siliceous rock, granulite, quartzite, and slate are featured with low susceptibilities not exceeding $1,000 \times 10^{-5} \mathrm{SI}$, and the average susceptibility of the Proterozoic is just $28 \times 10^{-5} \mathrm{SI}$; although maximum susceptibility (MS) of measured gneiss in the Proterozoic can reach $17,700 \times 10^{-5}$ SI. The only general high susceptibility stratum comes from Archean rocks, the average susceptibility can be as large as $2,300 \times 10^{-5} \mathrm{SI}$.

The main outcrop of Archean is located in Kuruktag and the northern slope of the Altun Mountains. The Tograk Brak complex $\left(\mathrm{Ar}_{2} \mathrm{tg}\right)$ in Kuruktag is a set of meso-hypo metamorphic rocks, and the main rock type is migmatite (AS $\left.=100 \times 10^{-5} \mathrm{SI}\right)$, plagioclase granitic gneiss $\left(\mathrm{AS}=600 \times 10^{-5} \mathrm{SI}\right.$, MS $=5,700 \times 10^{-5} \mathrm{SI}$, and biotite amphibole plagiogneiss containing a small quantity of granulite, mylonite, and plagioclase amphibolite $\left(\mathrm{AS}=400 \times 10^{-5} \mathrm{SI}, \mathrm{MS}=1,300 \times\right.$ $10^{-5} \mathrm{SI}$ ). The AS of phlogopite diopside rock, magmatic carbonate rock, and phlogopite rock of $\mathrm{Ar}_{2}$ tg located in the Vermiculite Mining Area is $4,000 \times 10^{-5}$ SI. The Milan metamorphic suite $\left(\mathrm{Ar}_{2} \mathrm{~m} 1\right)$ located in the northern slope of the Altun Mountains consists of granulite (AS $=1,500 \times 10^{-5} \mathrm{SI}, \mathrm{MS}=2000 \times 10^{-5} \mathrm{SI}$ ), plagioclase amphibolite, gneiss $\left(\mathrm{AS}=1,500 \times 10^{-5} \mathrm{SI}, \mathrm{MS}=\right.$ $\left.11,500 \times 10^{-5} \mathrm{SI}\right)$, granulite, and migmatite. 


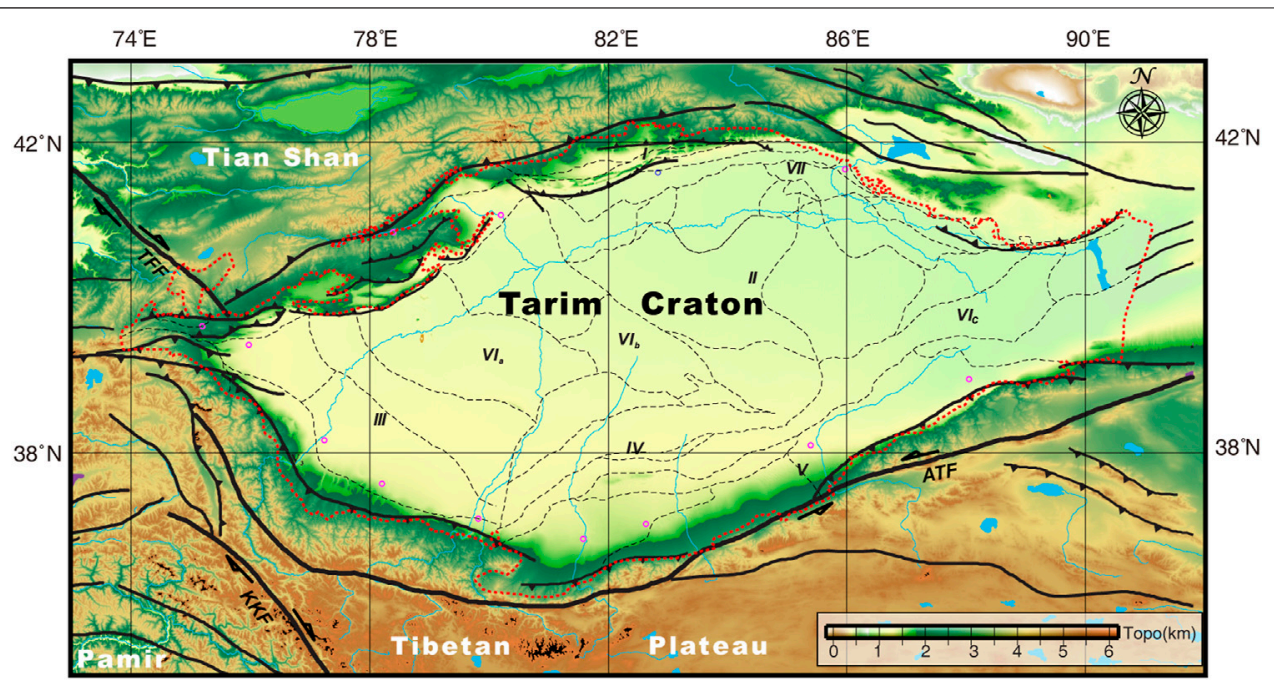

FIGURE 1 | Topography and tectonic map of the Tarim Basin and its environs. The red dashed line outlines the Tarim Basin, within which the dashed black lines are the boundaries of subdomains corresponding to basinal structural units. The black lines represent major faults and sutures. Marks and abbreviations are as follows: Depression Domain: I: Kuche, II: Northern, III: Southwestern, IV: Tanggu, V: Southeastern; Uplift Domain: Vla: Bachu, VIb: Tazhong, VI : Southeastern, VII: Tabei. ATF: Altyn-Tagh Fault, TFF: Talas-Fergana Fault, KF: Karakorum Fault. The tectonic units were modified from XJBGMR (Bureau of Geology and Mineral Resources of Xinjiang Province) (1993) and the topography is derived from the ETOPO1 model available from the NOAA database (http://www.ngdc.noaa.gov/mgg/global/global. html).

There are some Proterozoic and Paleozoic magmatic rocks located in the Southeastern Tianshan and Altun Mountains. The magnetism of magmatic rocks is related to the silicon dioxide content in rocks. The AS of basic-ultrabasic magmatic rock (such as gabbro and diabase) can reach $7,000 \times 10^{-5}$ SI. However the AS of intermediate and acidic intrusive rocks is just $280 \times 10^{-5} \mathrm{SI}$ and $60 \times 10^{-5} \mathrm{SI}$, respectively (Table 2 ) .

In conclusion, almost all of the AS of Phanerozoic stratum is low; the AS of Proterozoic sedimentary and metamorphic rocks is generally low although some measured gneiss has high value. The AS of magmatic rock varies in a wide range, however the acidic and intermediate magmatic rocks are more widely distributed than the basic and ultrabasic magmatic rock. So the Archean metamorphic rock is the only regional rock type with high susceptibility.

\section{DATA}

\section{Aeromagnetic Survey}

Aeromagnetic data were sourced from China Aero Geophysical Survey \& Remote Sensing Center for Natural Resources (AGRS). In order to study the basement and crust structure of the Tarim Basin, more than 75,472.4 line kilometers of total-field magnetic data were flown in a south-north direction with a line spacing of $0.5 \mathrm{~km}$ and with the east-west trending tie lines at $10 \mathrm{~km}$ intervals over all areas in 2015-2016, covering an area of nearly $39,337.3 \mathrm{~km}^{2}$ at an average altitude of $666.5 \mathrm{~m}$ above the ground (Figure 2). The survey was conducted by installing a helium optically pumped magnetometer HC-2000 on a Cessna208B airplane.
The quality control of field aeromagnetic data including instrument stability, magnetic fourth-order difference statistics, magnetic diurnal variation measurement, and field aeromagnetic data processing including coordinate transformation, calculation and correction of normal geomagnetic field, correction of the magnetic diurnal variation, cross line leveling, gridding, and so on were also operated on the AGRS-Geoprobe software. Then the magnetic data were reduced to the pole (RTP) by variable inclination (Arkani-Hamed, 1988; Li D et al., 2014; Li Q et al., 2014; Li et al., 2018) for the purpose of facilitating geologic interpretation, which is a standard geophysical technique to center magnetic anomalies to positions directly above their sources (Baranov and Naudy, 1964; Blakely, 1996; Goodge and Finn, 2010).

\section{Characteristics of Magnetic Anomalies}

The horizontal location of highly magnetic anomalies with RTP moved towards the north (Figures 3A,B). In this study, all the processes and interpretations referred to magnetic anomalies with RTP. The amplitude of aeromagnetic anomalies varies between -335 and $332 \mathrm{nT}$ in the Eastern Tarim Basin (Figure 3B). The magnetic anomalies show a gently variational banded shape with the direction of NEE, NE, or NW in the central and northern zones, and the highfrequency signals become more important in the southern zone with NE direction and in the northernmost zone with EW direction. All of the anomalies are the response of basement property and the faults inside the basement. Based on the characteristics of magnetic anomalies, four large magnetic zones can be classified as: the Kongquehe Magnetic Zone with low magnetic anomalies (I), the Northeastern Mangal Magnetic Zone 


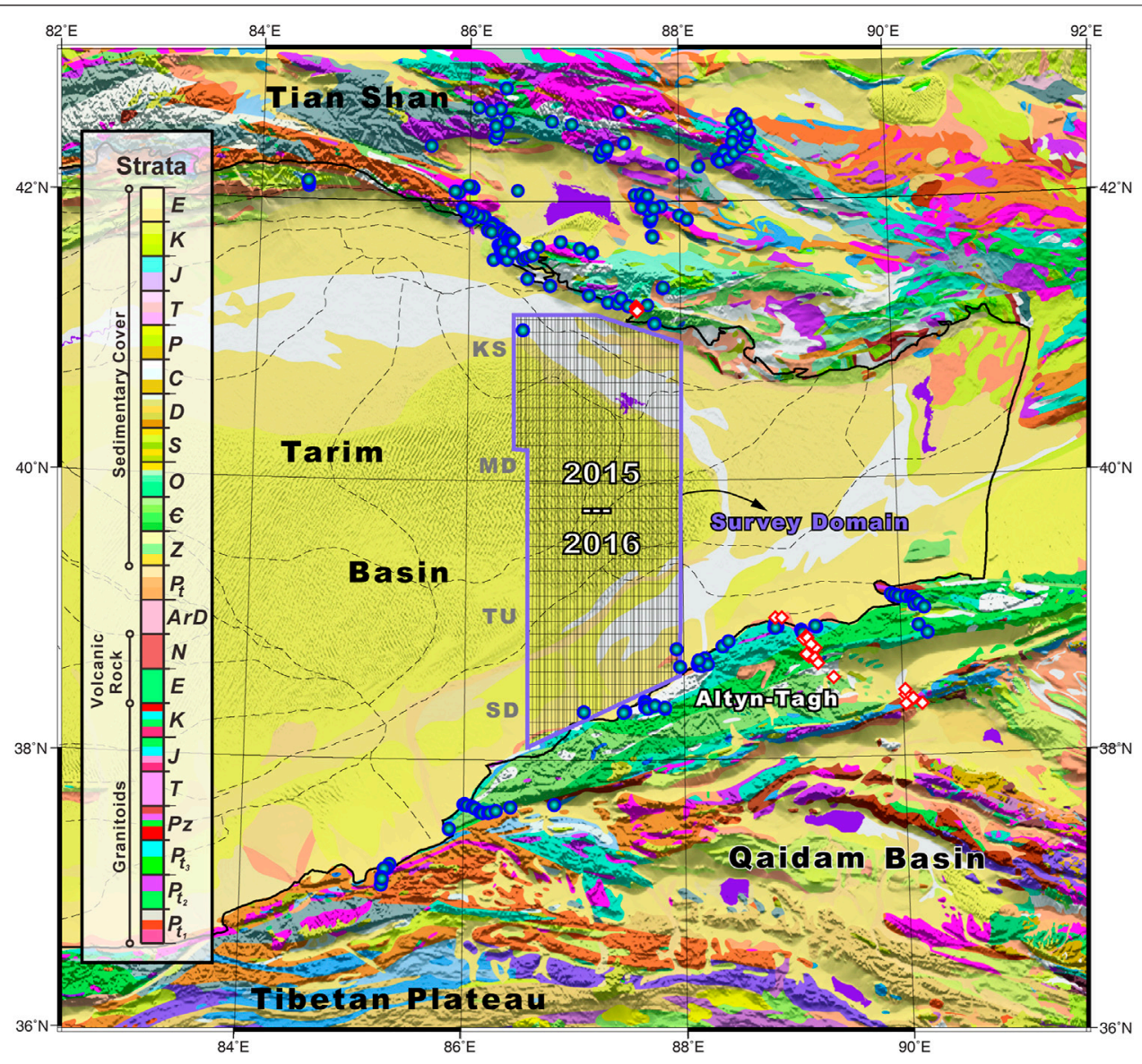

FIGURE 2 | Simplified geological map of the Eastern Tarim Basin and its tectonic units (XJBGMR (Bureau of Geology and Mineral Resources of Xinjiang Province), 1993). The blue polygon is the region of aeromagnetic data acquired in this study, the lines inside the blue polygon are survey flight paths. The blue circles and red diamonds indicate the locations for measuring the magnetic susceptibility of sampling rocks by us and our coworkers, respectively. The measured magnetic measurements are compiled in Table 1 and Table 2. Abbreviations are as follows: KS: Kongquehe Slope, MD: Mangal Depression, TU: Tadong Uplift, SD: Southeastern Depression.

TABLE 1 | Measured magnetic susceptibility of exposure strata in the Eastern Tarim Basin.

Era

Lithology

Sand, gravel soils, loess

Sandstone, mudstone, sand shale

Sandstone, mudstone, sand shale

Sandstone

Sandstone, mudstone, conglomerate

Sandstone, limestone, mudstone, volcanic breccia, pyroclastic rock

Limestone, siliceous rock, sandstone

Limestone, sandstone, siliceous rock, pyroclastic rock

Sandstone, mudstone, limestone, dolomite

Limestone

Sandstone, conglomerate, tillite

Schist, gneiss, marble, slate, quartzite

Igneous carbonatite, phlogopite rock, hornblende gneiss, banded gneiss, granite gneiss, phlogopite diopside

\begin{tabular}{cccc}
\multicolumn{4}{c}{ Magnetic susceptibility $\left(\times \mathbf{1 0}^{-\mathbf{5}} \mathbf{S I}\right)$} \\
\hline Measuring points & Min & Max & Mean \\
635 & 0 & 278 & 47 \\
112 & 0 & 180 & 33 \\
52 & 0 & 30 & 8 \\
148 & 0 & 270 & 12 \\
930 & 0 & 110 & 15 \\
237 & 0 & 1,400 & 40 \\
105 & 0 & 109 & 5 \\
77 & 0 & 45 & 8 \\
215 & 0 & 81 & 13 \\
17 & 0 & 26 & 1 \\
139 & 0 & 75 & 21 \\
1,100 & 0 & 17,710 & 28 \\
252 & 18 & 25,600 & 2,294
\end{tabular}

with moderate magnetic anomalies (II), the Central Tadong Magnetic Zone with high magnetic anomalies (III), and the Qiemo-Ruoqiang Magnetic Zone with variational magnetic anomalies (IV) which was subdivided into the Qiemo-Kurgan Subzone with low magnetic anomalies $\left(\mathrm{IV}_{1}\right)$, the Tile Shi Xia Subzone with high magnetic anomalies $\left(\mathrm{IV}_{2}\right)$, the Western 
TABLE 2 | Measured magnetic susceptibility of intrusive rocks in the Eastern Tarim Basin.

Lithology

Gneissic granite, granite, granodiorite, monzonitic granite, migmatitic granite

Diorite, feldspar andesite porphyrite

Diabase, ultrabasic rock

\begin{tabular}{cccc}
\multicolumn{4}{c}{ Magnetic susceptibility $\left(\times \mathbf{1 0 ^ { - 5 }} \mathbf{~ S I}\right)$} \\
\hline Measuring points & Min & Max & Mean \\
435 & 0 & 1,000 & 60 \\
132 & 10 & 4,900 & 281 \\
49 & 140 & 27,900 & 7,065
\end{tabular}
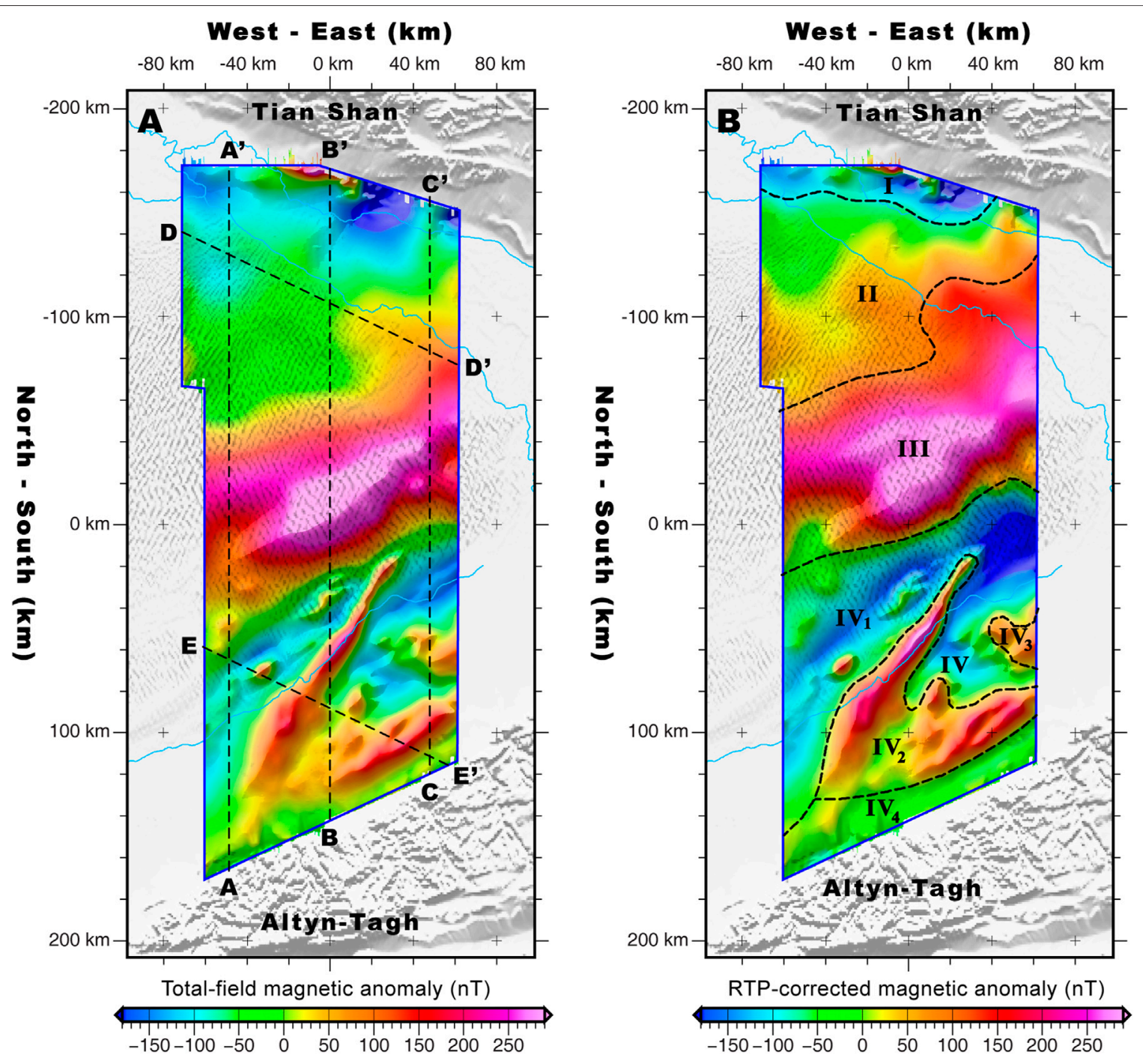

FIGURE 3 | (A) Map of magnetic anomalies (without RTP) with five superimposed profiles used for forward modeling, the dotted lines are the locations of profiles.

(B) The subregions and their marks of major domains of magnetic anomalies (RTP), the dotted lines are the boundaries of major domains. For detailed explanations of the marks, see the text. Both maps are overlain on the shaded ETOPO model (www.ngdc.noaa.gov/mgg/global.html).

Ruoqiang Subzone with high magnetic anomalies $\left(\mathrm{IV}_{3}\right)$, and the Tal Aqz Subzone with variational magnetic anomalies $\left(\mathrm{IV}_{4}\right)$ (Figure 3B).

The range of magnetic anomalies variation is limited from -300 to $200 \mathrm{nT}$ in the Kongquehe Magnetic Zone, where the high-frequency positive anomalies superimpose on the negative magnetic background. The Northeastern Mangal Magnetic
Zone shows wide variational moderate magnetic characteristics with the magnetic anomalies value from -40 to $150 \mathrm{nT}$. As for the Central Tadong Magnetic Zone, it is the eastern part of the well-known Central Highly Magnetic Anomaly Belt with the magnetic value varying between 100 and $350 \mathrm{nT}$. The Qiemo-Ruoqiang Magnetic Zone is characterized with the most complex magnetic anomalies 


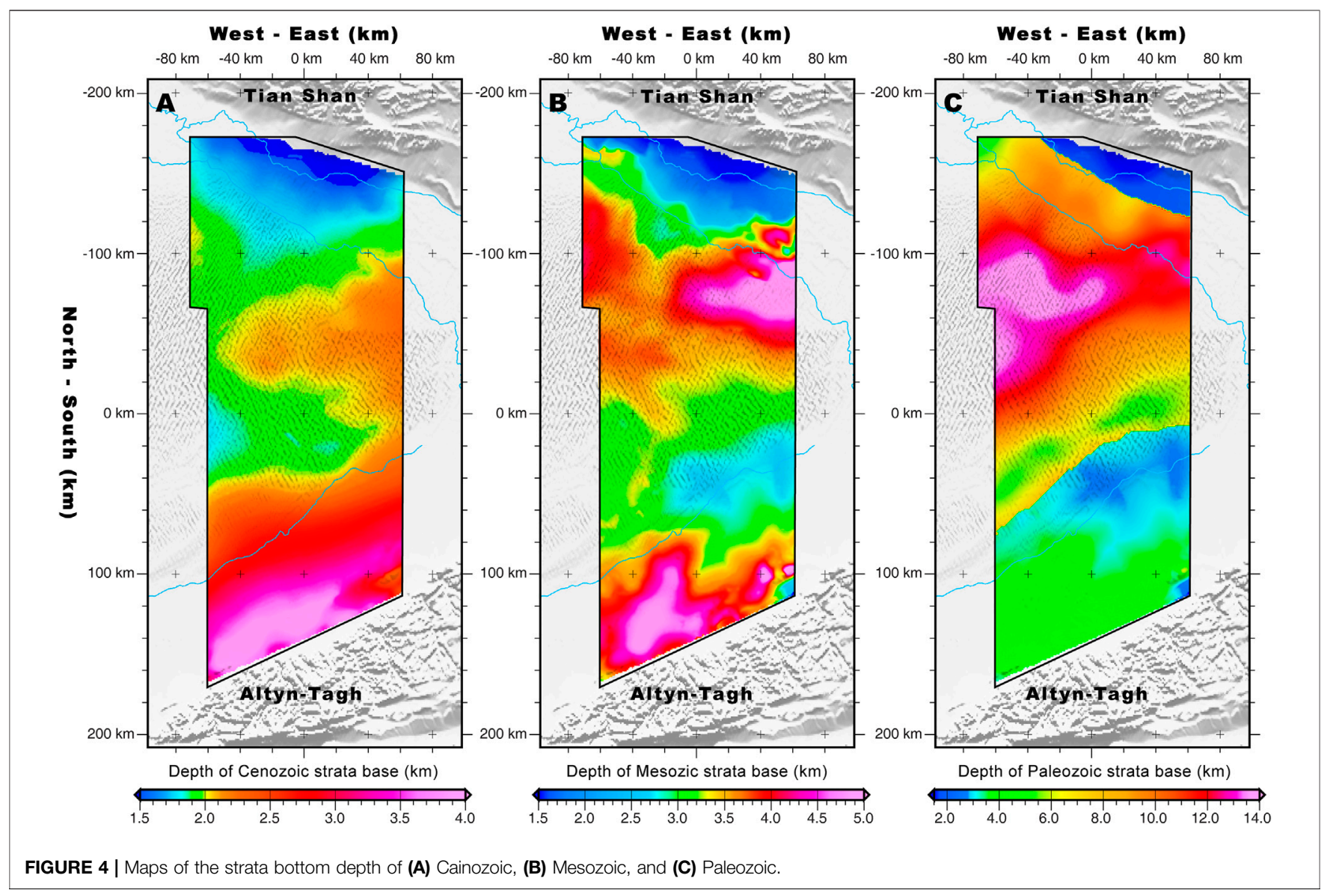

with a lot of elliptic and stripped high magnetic anomalies superimposing on a negative background, and the magnetic anomalies variation extent can be from -220 to $320 \mathrm{nT}$.

\section{Seismic Reflection Data}

Sedimentary interfaces and upper interfaces of Precambrian stratum (Figure 4) are from the Bureau of Geophysical Prospecting, China National Petroleum Corporation. Considering the low average susceptibility in the Phanerozoic stratum, and the disputed Neoproterozoic stratum distribution, it is reasonable to assume the top surface of the basement (Precambrian) as the main magnetic upper interface.

\section{METHOD AND RESULT}

\section{Magnetic Gradient-Processing Methods}

Large basement faults have certain effects on aeromagnetic anomalies: the regional magnetic anomalies are mainly caused by the characteristics of the basin's base, basement faults, and volcanism (Crawford et al., 2010; Yang et al., 2012). The contact zones or suture belts between different lithologic crystalline basements or different blocks could produce the steepening gradient until anomalies are flattened within each magnetic block (Cordell and McCafferty, 1989).
The vertical derivative (VDR) and the total horizontal derivative (THDR) are effective methods for delineating crust lineament structure and boundary identification. The VDR and THDR convert the magnetic anomaly gradient bands into zero and the maximum value respectively for easy-to-identify and accurate-toposition (Phillips, 2000; Grauch, 2001; Verduzco et al., 2004; Wang et al., 2021). The expression of $\operatorname{THDR}(x, y)$ is as follows (Grauch and Cordell, 1987; Miller and Singh, 1994):

$$
\operatorname{THDR}(x, y)=\sqrt{\left(\frac{\partial \Delta T}{\partial x}\right)^{2}+\left(\frac{\partial \Delta T}{\partial y}\right)^{2}}
$$

And the expression of $\operatorname{VDR}(x, y)$ is as follows (Verduzco et al., 2004):

$$
\operatorname{VDR}(x, y)=\frac{\partial \Delta T}{\partial z}
$$

Another effective method to assess the structure units is widely used tilt-derivative (TDR) because it can normalize magnetic amplitude and successfully visualize delicate anomalies within the basement (Miller and Singh, 1994; Thurston and Smith, 1997; Verduzco et al., 2004). This method is commonly applied to continental potential field datasets for it clearly defines anomaly edges, it equalizes amplitudes of anomalies, and will produce 


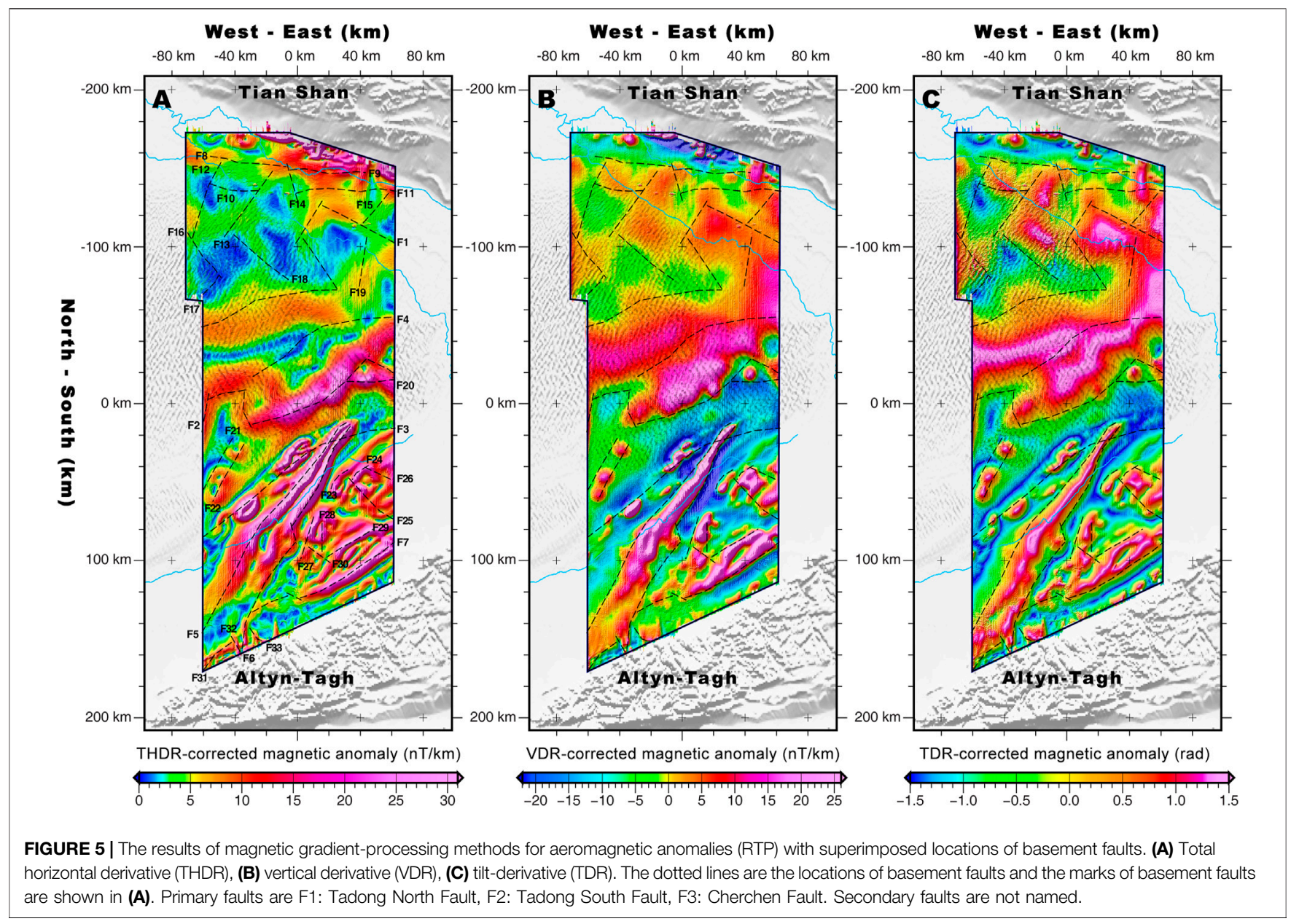

useful magnetic responses for induced and remanent magnetized anomalies (Verduzco et al., 2004; Wang and Meng, 2019). The expression of $\operatorname{TDR}(x, y)$ can be written as follows (Miller and Singh, 1994; Thurston and Smith, 1997):

$$
\operatorname{TDR}(x, y)=\arctan \left[\frac{\operatorname{VDR}(x, y)}{\operatorname{THDR}(x, y)}\right]
$$

Where $\operatorname{VDR}(x, y)$ and $\operatorname{THDR}(x, y)$ are the first vertical and total horizontal derivatives (Eqs 1, 2), respectively, of the total magnetic intensity $\Delta T$.

Here $\Delta T$ and its VDR, THDR, and TDR method are synthetically adopted to identify the lineament structures of the crust. To better understand the possible large-scale fault and suture lines, the magnetic anomalies are upward continued to 5 and $10 \mathrm{~km}$, respectively (Blakely, 1996).

\section{Profile Forward Modeling}

2.5D forward modeling is an effective method of combining magnetic and seismic interfaces and other useful information to produce a constraint solution especially when the direction of the profile is perpendicular to the direction of the structural strike, and this advantage condition is satisfied here because the direction of the structural strike is EW or northeast to southwest, while the direction of our profile is $\mathrm{SN}$ or northwest to southeast. The forward modeling of magnetic data was conducted by using an interactive, iterative technique within the Geosoft GM-SYS software, which is widely used because it can compute the magnetic forward modeling curve by subdividing the underground models and assigning magnetic susceptibilities for them. Every subdivision of underground models is a specified 2.5D horizontal prism whose strike is perpendicular to the fitting profile, and the methodology for calculating the magnetic response comes from Talwani and Heirtzler (1964). The initial parameters such as magnetic susceptibilities and interfaces are based on the material mentioned in previous sections. The interface information is relatively reliable because it comes from seismic reflection and refraction data. Therefore, only magnetic susceptibilities are varied to produce a consistent model solution, which can best fit the observed anomalies.

The remanent magnetization is not considered to be important and only the induced magnetization is simulated because the main source of magnetic anomalies is the crystalline basement, especially the Archean basement. The 

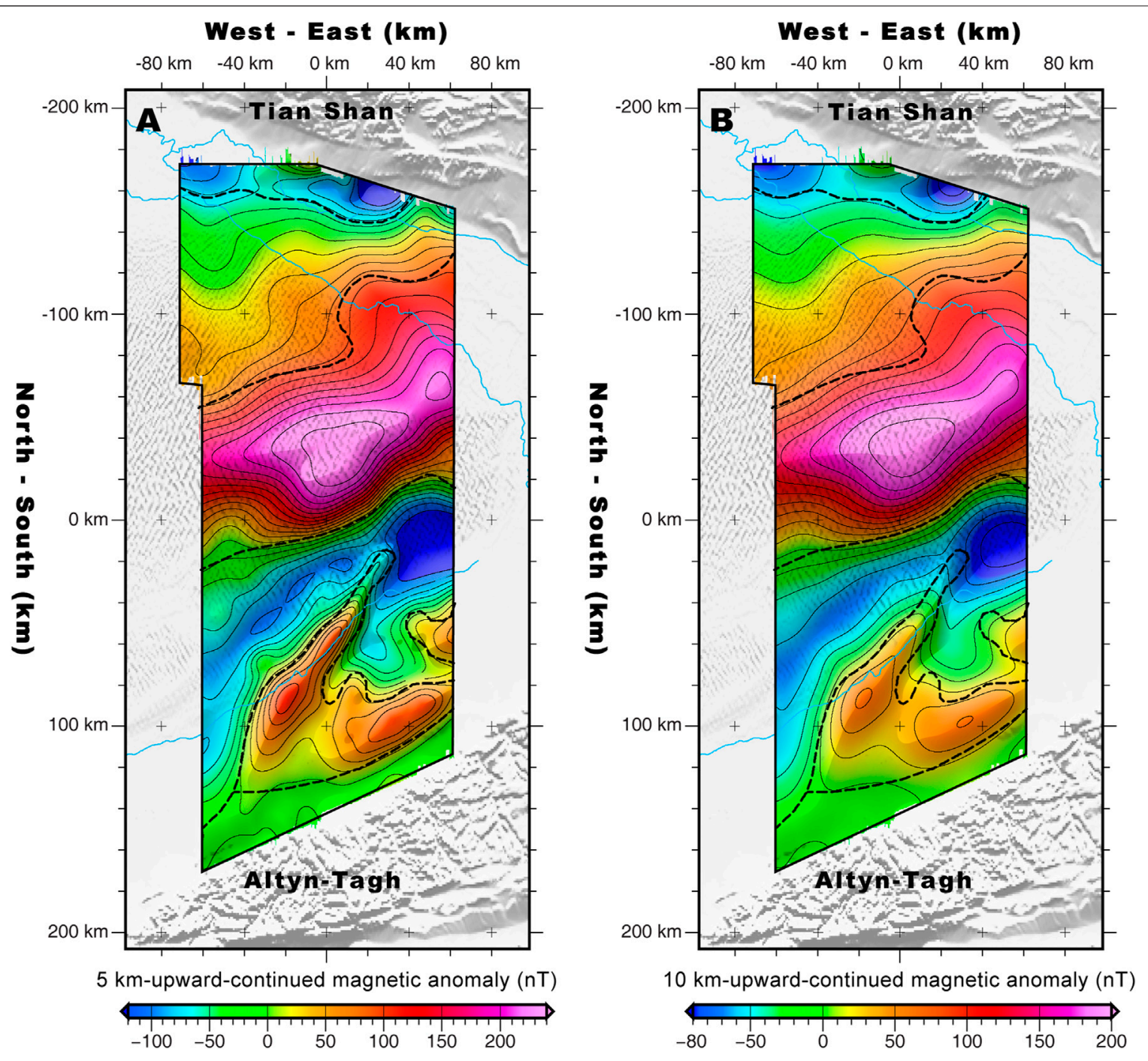

FIGURE 6 | Map of upward continuation to (A) $5 \mathrm{~km}$ and (B) $10 \mathrm{~km}$ of magnetic anomalies (RTP), and the boundaries of subregions of magnetic anomalies.

uniformly geomagnetic intensity of $54,615 \mathrm{nT}$ and uniformly magnetized direction with inclination of $59.4^{\circ}$ and declination of $2.1^{\circ}$ were calculated in the Eastern Tarim Carton. A previous research regarded the upper crust as the main magnetic layer and estimated the thickness of the upper crustal magnetic layer by using spectral analysis (Finn and Ravat, 2004), however the spectral analysis has huge uncertainty (Gao et al., 2015; Xiong et al., 2016b; Li et al., 2017; Xu et al., 2021), especially for a small region about $40,000 \mathrm{~km}^{2}$ like our research area. The moderately geothermal gradient of $12.5^{\circ}$ per $\mathrm{km}$ and thus a $55 \mathrm{~km}$ thick magnetic layer were assumed for the Precambrian craton crust in the United States interior (Friedman et al., 2014), which is comparable with the crustal thickness of about $50 \mathrm{~km}$ for the Eastern Tarim Craton resulted from the wide-angle reflection/ refraction seismic profile (Teng et al., 2013; Teng et al., 2014). Therefore, we hypothesized that the Moho interface and top surface of the Precambrian are the bottom and top of the magnetic layer, and the susceptibility in each block is uniform.

\section{Result}

Based on the susceptibility difference in adjacent blocks of forward modeling, faults extended distances, sizes, and degree of the control on the basin's deposition (Lin et al., 2015), the faults were classified into primary and secondary faults (Figure 5, Figure 6).

The distribution maps (Figure 5, Figure 6) of basement faults show three primary basement faults (from F1 to F3, Figure 5A) and thirty secondary basement faults (from F4 to F33, Figure 5A). Almost all the basement faults are located along the zero line of VDR and TDR or the maximum line of THDR. The strikes of basement faults are NE, NW, or approximate EW. The primary basement faults distribute mainly along the NE direction with long extension or large displacement or huge susceptibilities difference between two sides of faults. The strikes of marginal basement faults are consistent with the basin's boundaries. The magnetic anomalies of upward continuation 5 and $10 \mathrm{~km}$ have an obvious response to primary basement faults, but have no or little response to 

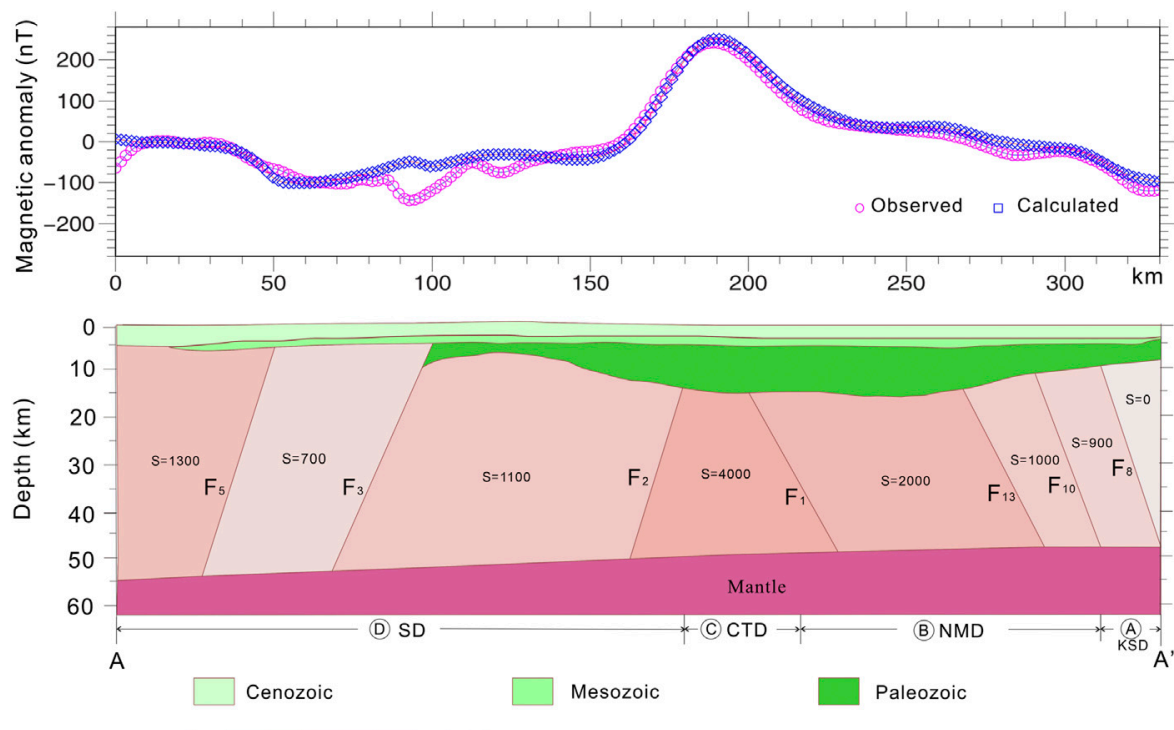

Crystalline basement model magnetic susceptibilities $\left(\times 10^{-5} \mathrm{SI}\right)$

FIGURE 7 | Profile AA' for magnetic forward modeling, profile location showed in Figure 3A. Top: observed and calculated magnetic data; bottom: lithologic profile of crust and uppermost mantle with modeled magnetic susceptibilities. F1 and so on are the faults of the basement; "S" means susceptibility; (A) and so on are the marks of crystalline basement domains, and "KSD" and so on are the abbreviations of names of crystalline basement domains, for better understanding of the marks and abbreviations please see Figure 12 and the text.
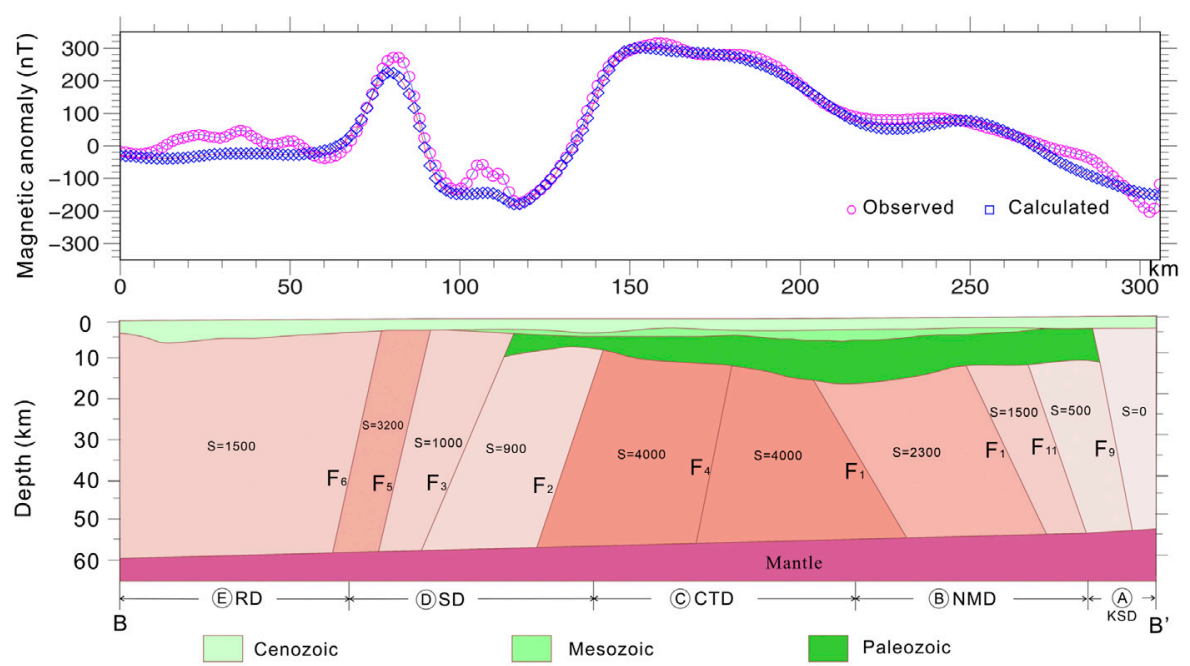

Crystalline basement model magnetic susceptibilities $\left(\times 10^{-5} \mathrm{SI}\right)$

FIGURE 8 | Profile BB' for magnetic forward modeling, profile location showed in Figure 3A. See Figure $\mathbf{7}$ for other figure descriptions.

secondary basement faults (Figure 5, Figure 6). The Tadong North Fault (F1), and the Tadong South Fault (F2), are the most important basement faults that cause the steep magnetic gradient belt. F3, namely the notable Cherchen Fault, is obvious in the seismic profile because of its large vertical displacement of $3 \mathrm{~km}$. However it fails to lead to an obvious gradient in the magnetic anomalies map.
Forward modeling (Figures 7-11) showed that F1 and the faults to the north of F1 dip northwards; on the contrary, F2 and the faults to the south of F2 dip southwards. The susceptibilities of basement blocks to the south of F2 and north of F1 are generally low while those of basement blocks between F1 and F2 are as high as $4000 \times 10^{-5}$ SI. The basement blocks with moderate susceptibilities mainly distribute between F1 and F8, F9, and 

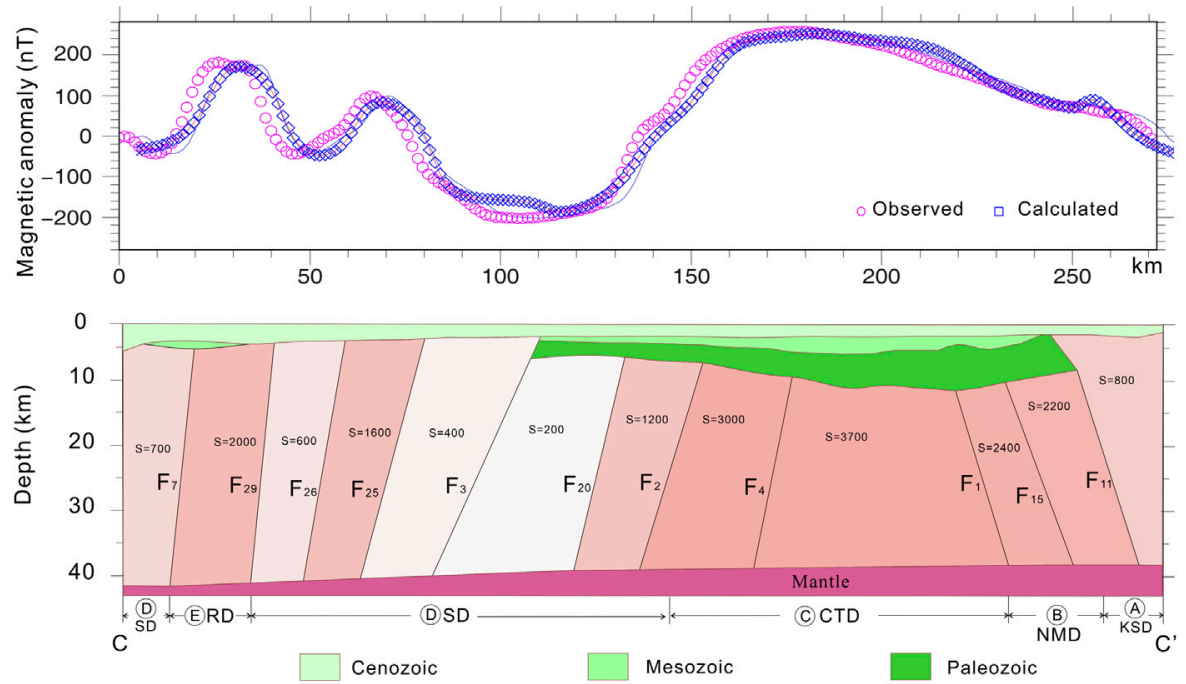

\begin{tabular}{|l|l|l|l|l|l|l|l|l|l|l|}
\hline & & & & & & & & & & Crystalline basement model magnetic susceptibilities $\left(\times 10^{-5} \mathrm{SI}\right)$
\end{tabular}

FIGURE 9 | Profile $\mathrm{CC}^{\prime}$ for magnetic forward modeling, profile location showed in Figure 3A. See Figure $\mathbf{7}$ for other figure descriptions.
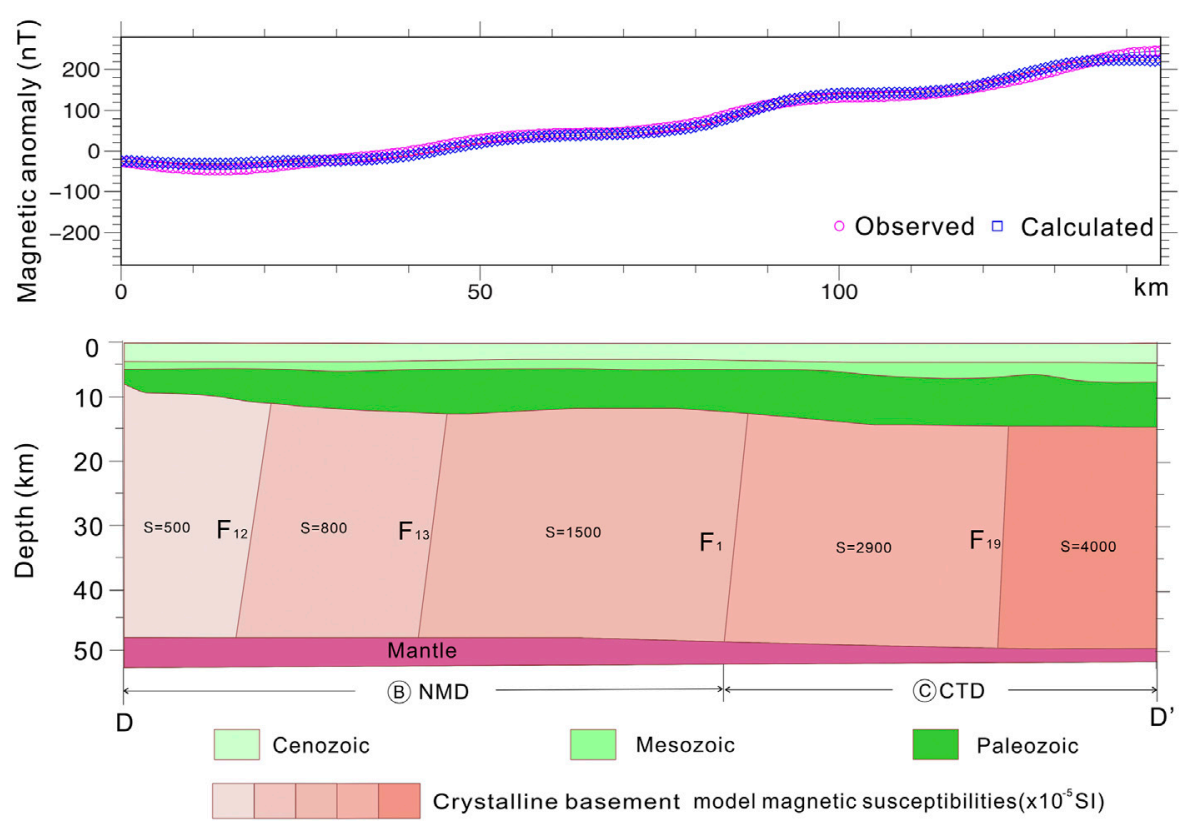

FIGURE 10 | Profile DD' for magnetic forward modeling, profile location showed in Figure 2A. See Figure 7 for other figure descriptions.

between F5 and F7. Whereas, the basement blocks with the lowest susceptibilities are located in the north of F8, F9, and close to F3. As our target is to recognize the major faults, scope of extensive magmatic rocks, and the susceptibilities of large blocks, so some high-frequency or small-scale magnetic anomalies were not matched delicately by designing small blocks, such as the magnetic anomaly labeled with the dotted line ellipse (Figure 11).

\section{DISCUSSION}

Based on the strikes, amplitudes, and textures of the magnetic anomaly map and forward modeling, five crystalline basement domains (Figure 12) were defined: 1) the Kongquehe Slope Domain (KSD) with a weakly magnetic basement containing moderate magnetic magmatic rocks; 2) the Northeastern Mangal 

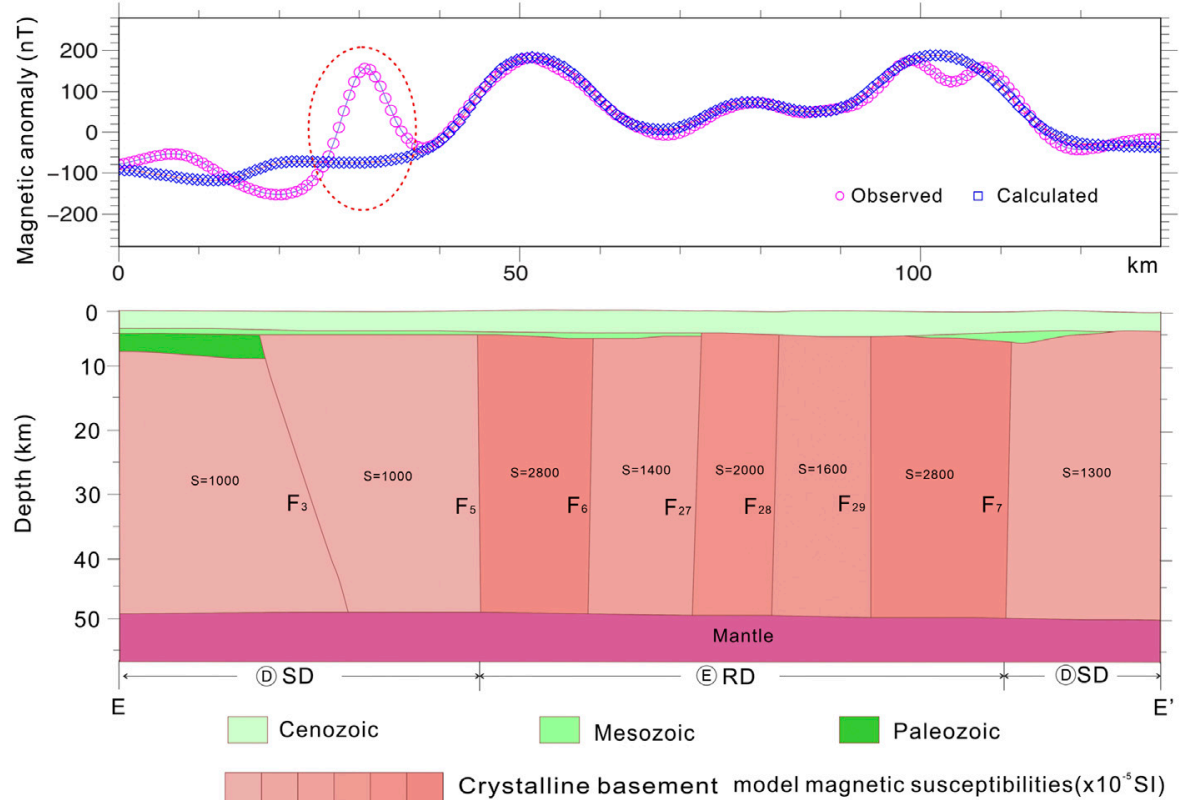

FIGURE 11 | Profile EE' for magnetic forward modeling, profile location showed in Figure 3A. The observed high-frequency magnetic anomaly labeled with a dotted line ellipse may be the response of magmatic rock. See Figure $\mathbf{7}$ for other figure descriptions.

Domain (NMD) with a gradually variational moderate magnetic basement from south to north modified by the Neoproterozoic rift; 3) the Central Tadong Domain (CTD), including the southern Mangal Depression and northern Tadong Uplift, with the strongly magnetic unmodified Archean basement; 4) the Southeastern Domain (SD), including the southern Tadong Uplift, with a weakly magnetic basement containing a few strongly magnetic magmatic rocks; and 5) the Ruoqiang Domain (RD) with a moderately to strongly magnetic basement with a lot of magmatic rocks. The crystalline basement characteristics and their geological meaning were interpreted by combining magnetic anomalies, the strikes, dips of basement faults, and susceptibilities calculated from profile forward modeling and measured in the field.

(1) The magnetic intensity generally has a mirror image relationship with the depth of the basement. For example, the Kongquehe Slope Domain, Southeastern Domain, especially the zone close to the Cherchen Fault (F3), all have a relatively shallow basement depth, however the magnetic anomaly intensity corresponding to those domains possesses low value. According to the characteristics mentioned above, it can be inferred that the magnetic anomaly intensity is mainly controlled by the susceptibilities (lithologic property) rather than by the basement depth (fault displacement), suggesting that the forward modeling method mainly considering the susceptibility lateral variation is reasonable.

(2) Based on a lot of tests for satisfying the magnetic anomalies, it was found that the Tadong North Fault (F1) and faults to the north of F1 mainly dip northwards, while on the contrary, the
Tadong South Fault (F2) and faults to the south of F2 mainly dip southwards, which is consistent with industry seismic results (Laborde et al., 2019). Hence, it means that F1 and F2 are both important boundary faults that control the crustal structure, and therefore influenced the crustal activities during geological history.

(3) Where is the Archean basement? How did the Neoproterozoic rift activities influence the basement? The block between F1 and F2 shows the highest susceptibility with $4,000 \times 10^{-5} \mathrm{SI}$, which is higher than the average susceptibilities of Archean metamorphic rocks with 2,300 $\times 10^{-5} \mathrm{SI}$, but is consistent with the average susceptibilities of $\mathrm{Ar}_{2} \mathrm{tg}$ measured in the Vermiculite Mining Area located in Kuruktag. The Neoproterozoic rift center is located in the Northeastern Mangal Domain based on the seismic interpretation (Ren et al., 2017; He et al., 2019). If magmatic rocks related to the rift were the main factor to cause high magnetic anomalies, the Northeastern Mangal Domain would have the highest magnetic anomalies. However, this is not the case. From the magnetic anomalies interpretation map (Figure 12) and the forward modeling profiles (Figures 7-10), it can be seen that the magnetic anomaly values and the susceptibilities do not decrease sharply from south to north in the Central Tadong Domain and Northeastern Mangal Domain. Furthermore, the disordered strikes of the northern boundary (Yang et al., 2012; Lin et al., 2015; He et al., 2019) of the Central Highly Magnetic Anomaly Belt reveal a possible extension in the Northeastern Mangal Domain. Considering the similar evolution history of the Northeastern Mangal Domain and Central Tadong Domain after 

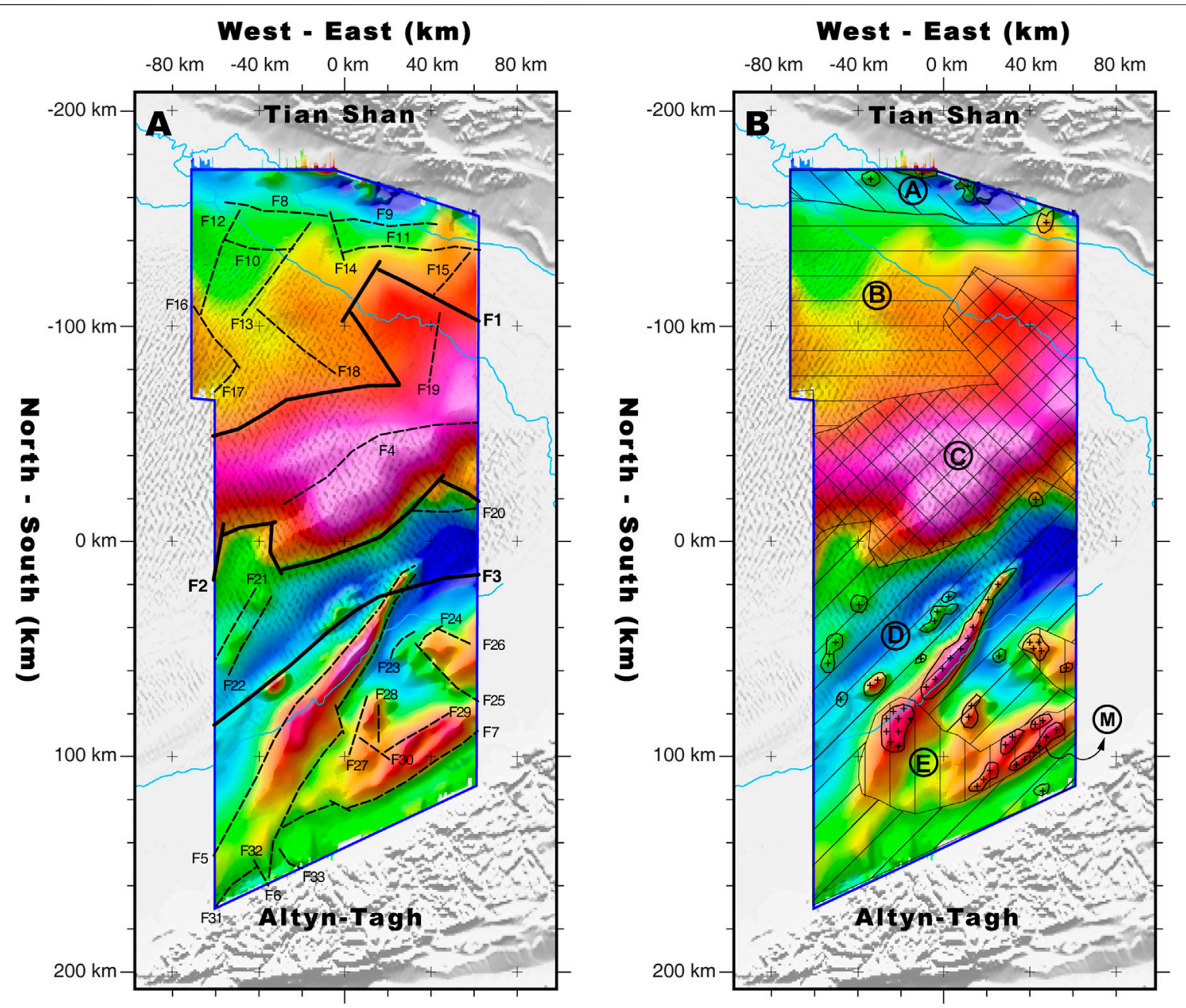

FIGURE 12 | Integrated interpretation map for faults and lithologic property of the crystalline basement. (A) Magnetic anomalies map with superimposed locations of basement faults, the primary faults numbered F1, F2, and F3 are highlighted in bold. (B) The domains and their marks of lithologic property of the crystalline basement. (A): Kongquehe Slope Domain (KSD); (B): Northeastern Mangal Domain (NMD); (C): Central Tadong Domain (CTD); (D): Southeastern Domain (SD); (): Ruogiang Domain (RD); (1): magmatic rocks. See detailed interpretation in the text.

Neoproterozoic rifting (Cui and Tang, 2011), and combining the northward dipping of faults in the Northeastern Mangal Domain calculated from forward modeling, we inferred that the Tarim Central Highly Magnetic Anomaly Belt located in the Central Tadong Domain is mainly caused by the Archean metamorphic rocks rather than the Neoproterozoic magmatic rocks related to rifting. On the contrary, the Northeastern Mangal Domain had a similar Archean crystalline basement to the Central Tadong Domain until it was modified and destructed by the Neoproterozoic rifting.

(4) The Tadong South Fault (F2) rather than Cherchen Fault (F3) is the most important basement fault controlling the Precambrian crustal evolution. A steep magnetic anomaly gradient exists along F2 rather than F3 from the magnetic anomaly interpretation map (Figure 12) and forward modeling profiles (Figures 7-9), although F3 has and F2 does not have a large fault displacement observed from the stratum depth contour (Figure 4C; Figures 7-9). In addition, the basement of Southeastern Domain is shallower than the Central Tadong Domain, but the magnetic anomaly values in the Central Tadong Domain are much higher than in the Southeastern Domain. We inferred that F3 is just an interior fault inside the Southeastern Domain, and F2 is an important Precambrian basement fault. What is the significance of F2 and the Tadong Uplift? Some Paleoproterozoic granites from boreholes in the south Tadong Uplift (located between F2 and F3) were tested and showed that granites are geodynamically related to subduction in an arc setting at the time of $19 \mathrm{Ga}$ (Yang et al., 2018). Thus, it was inferred that F2 is an ancient suture line formed during the Paleoproterozoic, in other words, a Paleoproterozoic orogenic crystalline basement exists in the Southeastern Domain.

(5) What is the relationship between the Tadong Uplift and Southeastern Depression? The Cherchen Fault (F3) developed during the late Early Paleozoic (Liu et al., 2012), and at the same time, extensive magmation occurred during the Silurian and Devonian related to the subduction of the 
Altun Ocean and the later orogenic movement (Sobel and Arnaud, 1999; Cowgill et al., 2003; Gehrels et al., 2003; Zhang et al., 2014). Furthermore, according to the seismic profile (Figures 7-9), the Cambrian stratum was folded obviously and the Ordovician stratum had a huge erosion in the Tadong Uplift, so that the upthrow occurred later than Ordovician. Apart from that, some isolated high-frequency magnetic anomalies distribute along F3. Thus it is reasonable to assume that the upthrow of the Tadong Uplift, the formation of faults and magmatic rocks to the south of F3 may all happen during the late Early Paleozoic related to the Altun Ocean.

\section{CONCLUSION}

In this study, magnetic gradient-processing methods were used to map the location of basement faults in the Eastern Tarim Basin based on newly acquired aeromagnetic data. Under the constraint of industry seismic data, we constructed five profiles via magnetic forward modeling, which provide effective constraint to recognize the dips of basement fabrics and the distributions of magnetic susceptibilities. This comprehensive study provided regional overview on the relationship between the basement property and tectonic activity.

(1) The Tarim Central Highly Magnetic Anomaly Belt was mainly caused by the Archean crystalline basement. The Northeastern Mangal Domain was equipped with a Neoproterozoic riftingmodified Archean crystalline basement, which was originally the same as the Central Tadong Domain.

(2) The weakly magnetic Southeastern Domain was sutured to the highly magnetic Central Tadong Domain along the Tadong South Fault during the Paleoproterozoic.

\section{REFERENCES}

Arkani-Hamed, J. (1988). Differential reduction-to-the-pole of regional magnetic anomalies. Geophysics 53 (12), 1592-1600. doi:10.1190/1.1442441

Baranov, V., and Naudy, H. (1964). Numerical Calculation of the Formula of Reduction to the Magnetic Pole. Geophysics 29 (1), 67-79. doi:10.1190/ 1.1439334

Blakely, R. J. (1996). Potential Theory in Gravity and Magnetic Applications. Cambridge University Press.

Cai, X. (2007). Main Factors Controlling Hydrocarbon Accumulation of MiddleAnd Large-Sized Oil and Gas fields and Their Distribution Rules in the Tarim Basin. Oil Gas Geology. 28 (6), 693-702.

Calignano, E., Sokoutis, D., Willingshofer, E., Gueydan, F., and Cloetingh, S. (2015). Strain Localization at the Margins of strong Lithospheric Domains: Insights from Analog Models. Tectonics 34 (3), 396-412. doi:10.1002/ 2014 tc003756

Charvet, J., Shu, L. S., and Laurent-Charvet, S. (2007). Paleozoic Structural and Geodynamic Evolution of Eastern Tianshan (NW China): Welding of the Tarim and Junggar Plates. Episodes J. Int. Geosci. 30 (3), 162-186.

Cordell, L., and McCafferty, A. E. (1989). A Terracing Operator for Physical Property Mapping with Potential Field Data. Geophysics 54 (5), 621-634. doi:10.1190/1.1442689

Cowgill, E., Yin, A., Harrison, T. M., and Xiao-Feng, W. (2003). Reconstruction of the Altyn Tagh Fault Based on U-Pb Geochronology: Role of Back Thrusts,
(3) The deformation of the Tadong Uplift, the evolution of the Cherchen Fault, and the distribution of magmatism along and to the south of the Cherchen Fault were all related to the subduction of the Altun terrane beneath the Southeastern Domain.

\section{DATA AVAILABILITY STATEMENT}

The original contributions presented in the study are included in the article; further inquiries can be directed to the corresponding authors.

\section{AUTHOR CONTRIBUTIONS}

$\mathrm{XK}$ conceived the study and interpreted the data; XK, XZ and FN wrote and edited the manuscript; XK processed the research data. Other co-authors jointly modified the manuscript.

\section{FUNDING}

This study was supported by two geological research programs (DD20160065, DD20190025) of China Geological Survey.

\section{ACKNOWLEDGMENTS}

We greatly thank all our coworkers for their efforts on the field work, including Xiawei Hu, Zhiqiang Zhu, Weiwei Peng, Zhibo Wang, Rui Li, Qi Wang, Chenyang Wang, Lei Shi, Xue Yang, Maiti Xu, Shengbo Geng, Ruohan Wu, and Xi Xu.

Mantle Sutures, and Heterogeneous Crustal Strength in Forming the Tibetan Plateau. J. Geophys. Res. Solid Earth 108 (B7). doi:10.1029/2002jb002080

Craig, T. J., Copley, A., and Jackson, J. (2012). Thermal and Tectonic Consequences of India Underthrusting Tibet. Earth Planet. Sci. Lett. 353-354, 231-239. doi:10.1016/j.epsl.2012.07.010

Crawford, B. L., Betts, P. G., and Aillères, L. (2010). An Aeromagnetic Approach to Revealing Buried Basement Structures and Their Role in the Proterozoic Evolution of the Wernecke Inlier, Yukon Territory, Canada. Tectonophysics 490 (1-2), 28-46. doi:10.1016/j.tecto.2010.04.025

Cui, J. W., and Tang, Z. M. (2011). Tectonic Framework of the Tarim Basin and its Tectonic Stress Field Analysis. Acta Petrologica Sinica 27 (1), 231-242.

Dayem, K. E., Molnar, P., Clark, M. K., and Houseman, G. A. (2009). Far-field Lithospheric Deformation in Tibet during continental Collision. Tectonics 28 (6). doi:10.1029/2008tc002344

Dong, S., Li, Z., and Jiang, L. (2016). The Early Paleozoic Sedimentary-Tectonic Evolution of the Circum-Mangar Areas, Tarim Block, NW China: Constraints from Integrated Detrital Records. Tectonophysics 682, 17-34. doi:10.1016/ j.tecto.2016.05.047

Finn, C. A., and Ravat, D. (2004). "December)Magnetic Depth Estimates and Their Potential for Constraining Crustal Composition and Heat Flow in Antarctica," in AGU Fall Meeting Abstracts, 2004, T11A-T1236.

Friedman, S. A., Feinberg, J. M., Ferré, E. C., Demory, F., Martín-Hernández, F., Conder, J. A., et al. (2014). Craton vs. Rift Uppermost Mantle Contributions to Magnetic Anomalies in the United States interior. Tectonophysics 624-625, 15-23. doi:10.1016/j.tecto.2014.04.023 
Gao, G., Kang, G., Bai, C., and Li, G. (2013). Distribution of the Crustal Magnetic Anomaly and Geological Structure in Xinjiang, China. J. Asian Earth Sci. 77, 12-20. doi:10.1016/j.jseaes.2013.08.014

Gao, G., Kang, G., Li, G., and Bai, C. (2015). Crustal Magnetic Anomaly and Curie Surface beneath Tarim Basin, China, and its Adjacent Area. Can. J. Earth Sci. 52 (6), 357-367. doi:10.1139/cjes-2014-0204

Gao, Z., and Fan, T. (2014). Intra-platform Tectono-Sedimentary Response to Geodynamic Transition along the Margin of the Tarim Basin, NW China. J. Asian Earth Sci. 96, 178-193. doi:10.1016/j.jseaes.2014.08.023

Gehrels, G. E., Yin, A., and Wang, X. F. (2003). Magmatic History of the Northeastern Tibetan Plateau. J. Geophys. Res. Solid Earth 108 (B9). doi:10.1029/2002jb001876

Goodge, J. W., and Finn, C. A. (2010). Glimpses of East Antarctica: Aeromagnetic and Satellite Magnetic View from the central Transantarctic Mountains of East Antarctica. J. Geophys. Res. Solid Earth 115 (B9). doi:10.1029/2009jb006890

Grauch, V. J. S., and Cordell, L. (1987). Limitations of Determining Density or Magnetic Boundaries from the Horizontal Gradient of Gravity or Pseudogravity Data. Geophysics 52 (1), 118-121. doi:10.1190/1.1442236

Grauch, V. J. S. (2001). Using High-Resolution Aeromagnetic Surveys to Map Subsurface Hydrogeology in Sediment-Filled Basins: A Case Study over the Rio Grande Rift, central New Mexico, USA. Exploration Geophys. 32 (3-4), 209-213. doi:10.1071/eg01209

Guo, N., Wu, C., and Fagin, S. (2015). Seismic Imaging of Complex Structures in the Tarim basin. J. Earth Sci. 26 (4), 586-591. doi:10.1007/s12583-015-0560-9

He, B., Jiao, C., Huang, T., Zhou, X., Cai, Z., Cao, Z., et al. (2019). Structural Architecture of Neoproterozoic Rifting Depression Groups in the Tarim Basin and Their Formation Dynamics. Sci. China Earth Sci. 62 (3), 529-549. doi:10.1007/s11430-018-9286-6

He, B., Jiao, C., Xu, Z., Cai, Z., Zhang, J., Liu, S., et al. (2016). The Paleotectonic and Paleogeography Reconstructions of the Tarim Basin and its Adjacent Areas (NW China) during the Late Early and Middle Paleozoic. Gondwana Res. 30, 191-206. doi:10.1016/j.gr.2015.09.011

He, D. (1995). Unconformities and Oil and Gas Accumulation in Tarim Basin. Acta Petrolei Sinica 16 (3), 14-21.

Hou, Z., and Yang, W. (2011). Multi-scale Inversion of Density Structure from Gravity Anomalies in Tarim Basin. Sci. China Earth Sci. 54 (3), 399-409. doi:10.1007/s11430-011-4169-2

Jiang, Z., Jiang, S., Lan, X., Wang, B., Huang, S., and Zhang, H. (2018). Neotectonic Evolution of the Tarim Basin Craton from Neogene to Quaternary. Int. Geology. Rev. 60 (10), 1213-1230. doi:10.1080/00206814.2017.1379365

Laborde, A., Barrier, L., Simoes, M., Li, H., Coudroy, T., Van der Woerd, J., et al. (2019). Cenozoic Deformation of the Tarim Basin and Surrounding Ranges (Xinjiang, China): A Regional Overview. Earth-Science Rev. 197, 102891. doi:10.1016/j.earscirev.2019.102891

Li, C. F., Lu, Y., and Wang, J. (2017). A Global Reference Model of Curie-point Depths Based on EMAG2. Sci. Rep. 7 (1), 45129-9. doi:10.1038/srep45129

Li, D., He, D., Yang, Y., and Lian, Y. (2014). Petrogenesis of Mid-carboniferous Volcanics and Granitic Intrusions from Western Junggar Basin Boreholes: Geodynamic Implications for the Central Asian Orogenic Belt in Northwest China. Int. Geology. Rev. 56 (13). doi:10.1080/00206814.2014.958766

Li, M., and Gao, J. (2010). Basement Faults and Volcanic Rock Distributions in the Ordos Basin. Sci. China Earth Sci. 53 (11), 1625-1633. doi:10.1007/s11430-0104042-8

Li, Q., Li, Q. C., and Yue-hong, J. (2014). The Varying Inclination Method for Magnetic Reduction to the Pole. Prog. Geophys. 29 (4), 1497-1502.

Li, S., Zhao, S., Liu, X., Cao, H., Yu, S., Li, X., et al. (2018). Closure of the ProtoTethys Ocean and Early Paleozoic Amalgamation of Microcontinental Blocks in East Asia. Earth-Science Rev. 186, 37-75. doi:10.1016/j.earscirev.2017.01.011

Liangjie, T., Lixin, Q., Haijun, Q., Lu, Y., Meng, L., Daqing, X., et al. (2012). Polyphase Differential Fault Movement and Hydrocarbon Accumulation of the Tarim Basin, NW China. Acta Petrologica Sinica 28 (8), 2569-2583.

Lin, B., Zhang, X., Xu, X., Yuan, J., Neng, Y., and Zhu, J. (2015). Features and Effects of Basement Faults on Deposition in the Tarim Basin. Earth-Science Rev. 145, 43-55. doi:10.1016/j.earscirev.2015.02.008

Lin, W., Chu, Y., Ji, W., Zhang, Z., Shi, Y., Wang, Z., Li, Z., and Wang, Q. (2013). Geochronological and Geochemical Constraints for a Middle Paleozoic continental Arc on the Northern Margin of the Tarim Block: Implications for the Paleozoic Tectonic Evolution of the South Chinese Tianshan. Lithosphere 5 (4), 355-381. doi:10.1130/1231.1

Liu, H., Somerville, I. D., Lin, C., and Zuo, S. (2016). Distribution of Palaeozoic Tectonic Superimposed Unconformities in the Tarim Basin, NW China: Significance for the Evolution of Palaeogeomorphology and Sedimentary Response. Geol. J. 51 (4), 627-651. doi:10.1002/gj.2664

Liu, X. W., Zheng, J. J., Yang, X., Sun, G. Q., Su, L., and Wang, Y. D. (2012). Sedimentology Revealment to Meso-Cenzoic Tectonic Movement Process of Altun Strike-Slip Fault. Nat. Gas Geosci. 01.

Ma, B. J., Qi, J. F., and Niu, S. Y. (2009). The Influence of Basement Fault on the Deformation of Complex Cover Blocks in a Uniform Stress Field-Enlightenment from Sandbox experiment. Earth Sci. Front. 16 (4), 105.

Miller, H. G., and Singh, V. (1994). Potential Field Tilt-A New Concept for Location of Potential Field Sources. J. Appl. Geophys. 32 (2-3), 213-217. doi:10.1016/0926-9851(94)90022-1

Morin, J., Jolivet, M., Robin, C., Heilbronn, G., Barrier, L., Bourquin, S., et al. (2018). Jurassic Paleogeography of the Tian Shan: an Evolution Driven by FarField Tectonics and Climate. Earth-science Rev. 187, 286-313. doi:10.1016/ j.earscirev.2018.10.007

Phillips, J. D. (2000). "Locating Magnetic Contacts: a Comparison of the Horizontal Gradient, Analytic Signal, and Local Wavenumber Methods," in SEG Technical Program Expanded Abstracts 2000 (Society of Exploration Geophysicists), 402-405. doi:10.1190/1.1816078

Pu, R., Dang, X., Xu, J., Guo, Q., and Yi, H. (2011). Permian Division and Correlation and Distribution of Volcanic Rocks of Tarim Basin. Acta Petrologica Sinica 27 (1), 166-180.

Ren, R., Guan, S., Wu, L., and Zhu, G. (2018). Evolution of the Neoproterozoic Rift Basins and its Implication for Oil and Gas Exploration in the Tarim Basin. Pet. Res. 3 (1), 66-76. doi:10.1016/j.ptlrs.2018.03.003

Ren, R., Guan, S., Wu, L., and Zhu, G. (2017). The north-south Differentiation Characteristics and its Enlightenment on Oil-Gas Exploration of the Neoproterozoic Rift basin, Tarim Basin. Acta Petrolei Sinica 38 (03), 255-266.

Sobel, E. R., and Arnaud, N. (1999). A Possible Middle Paleozoic Suture in the Altyn Tagh, NW China. Tectonics 18 (1), 64-74. doi:10.1029/1998tc900023

Talwani, M., and Heirtzler, J. R. (1964). Computation of Magnetic Anomalies Caused by Two Dimensional Structures of Arbitrary Shape. Comput. Mineral Industries GA Parks, 464-480.

Tang, L., Huang, T., Qiu, H., Qi, L., Yang, Y., Xie, D., et al. (2012). Salt-related Structure and Deformation Mechanism of the Middle-Lower Cambrian in the Middle-West Parts of the Central Uplift and Adjacent Areas of the Tarim Basin. Sci. China Earth Sci. 55 (7), 1123-1133. doi:10.1007/s11430-012-4414-3

Tang, L., Huang, T., Qiu, H., Wan, G., Li, M., Yang, Y., et al. (2014). Fault Systems and Their Mechanisms of the Formation and Distribution of the Tarim Basin, NW China. J. Earth Sci. 25 (1), 169-182. doi:10.1007/s12583-014-0410-1

Teng, J., Deng, Y., Badal, J., and Zhang, Y. (2014). Moho Depth, Seismicity and Seismogenic Structure in China mainland. Tectonophysics 627, 108-121. doi:10.1016/j.tecto.2013.11.008

Teng, J., Zhang, Z., Zhang, X., Wang, C., Gao, R., Yang, B., et al. (2013). Investigation of the Moho Discontinuity beneath the Chinese mainland Using Deep Seismic Sounding Profiles. Tectonophysics 609, 202-216. doi:10.1016/j.tecto.2012.11.024

Thurston, J. B., and Smith, R. S. (1997). Automatic Conversion of Magnetic Data to Depth, Dip, and Susceptibility Contrast Using the SPI (TM) Method. Geophysics 62 (3), 807-813. doi:10.1190/1.1444190

Tong, D., Zhang, J., Yang, H., Hu, D., and Ren, J. (2012). Fault System, Deformation Style and Development Mechanism of the Bachu Uplift, Tarim basin. J. Earth Sci. 23 (4), 529-541. doi:10.1007/s12583-012-0273-2

Tong, H., Cai, D., Wu, Y., Li, X., Li, X., and Meng, L. (2010). Activity Criterion of Pre-existing Fabrics in Non-homogeneous Deformation Domain. Sci. China Earth Sci. 53 (8), 1115-1125. doi:10.1007/s11430-010-3080-6

Tong, J., Zhang, X., Zhang, W., and Xiong, S. (2018). Marine Strata Morphology of the South Yellow Sea Based on High-Resolution Aeromagnetic and Airborne Gravity Data. Mar. Pet. Geology. 96, 429-440. doi:10.1016/ j.marpetgeo.2018.06.018

Verduzco, B., Fairhead, J. D., Green, C. M., and MacKenzie, C. (2004). New Insights into Magnetic Derivatives for Structural Mapping. The leading edge 23 (2), 116-119. doi:10.1190/1.1651454 
Wang, B. Q., Huang, Z. B., Ma, P. L., Pan, Z. Z., and Wang, L. L. (2009). Establishment of Division Standard, Evidence and Principle of Structural Units in Tarim Basin. Geotectonica et Metallogenia 33 (1), 86-93.

Wang, J., and Meng, X. (2019). An Aeromagnetic Investigation of the Dapai deposit in Fujian Province, South China: Structural and Mining Implications. Ore Geology. Rev. 112, 103061. doi:10.1016/j.oregeorev.2019.103061

Wang, Y., Chen, L., Yang, G., Wu, L., Xiao, A., Zhou, Y., et al. (2021). The Late Paleoproterozoic to Mesoproterozoic Rift System in the Ordos Basin and its Tectonic Implications: Insight from Analyses of Bouguer Gravity Anomalies. Precambrian Res. 352, 105964. doi:10.1016/j.precamres.2020.105964

Wu, L., Guan, S., Zhang, S., Yang, H., Jin, J., Zhang, X., et al. (2018). Neoproterozoic Stratigraphic Framework of the Tarim Craton in NW China: Implications for Rift Evolution. J. Asian Earth Sci. 158, 240-252. doi:10.1016/j.jseaes.2018.03.003

Xiong, S., Yang, H., Ding, Y., and Li, Z. (2016a). Characteristics of Chinese Continent Curie point Isotherm. Chin. J. Geophys. 59 (6), 643-657.

Xiong, S., Yang, H., Ding, Y., Li, Z., and Li, W. (2016b). Distribution of Igneous Rocks in China Revealed by Aeromagnetic Data. J. Asian Earth Sci. 129, 231-242. doi:10.1016/j.jseaes.2016.08.016

XJBGMR (Bureau of Geology and Mineral Resources of Xinjiang Province) (1993). Regional Geology of the Xinjiang Province. Beijing: Geological Publishing House. (in Chinese with English abstract).

Xu, M., Wang, L., Hu, D., Teng, R., and Zhong, K. (2002). Aeromagnetic Data Transforming and Basement Faults Analysis in the Western Tarim Basin. Chin. J. Geophys. 45, 157-164. doi:10.1002/cjg2.211

Xu, M. J., Wang, L. S., Zhong, K., and Hu, D. Z. (2005). Features of Gravitational and Magnetic fields in the Tarim basin and Basement Structure Analysis. Geol. J. China Universities 11 (4), 585.

Xu, X., Xiong, S., Tanaka, A., Zheng, Q., Kuang, X., Zhu, X., et al. (2021). Thermal Structure beneath the Tarim Craton and its Tectonic Implications. Front. Earth Sci. 9, 559. doi:10.3389/feart.2021.700114

Xu, Y.-G., Wei, X., Luo, Z.-Y., Liu, H.-Q., and Cao, J. (2014). The Early Permian Tarim Large Igneous Province: Main Characteristics and a Plume Incubation Model. Lithos 204, 20-35. doi:10.1016/j.lithos.2014.02.015

Xu, Z.-Q., He, B.-Z., Zhang, C.-L., Zhang, J.-X., Wang, Z.-M., and Cai, Z.-H. (2013). Tectonic Framework and Crustal Evolution of the Precambrian Basement of the Tarim Block in NW China: New Geochronological Evidence from Deep Drilling Samples. Precambrian Res. 235, 150-162. doi:10.1016/ j.precamres.2013.06.001

Yang, H., Wu, G., Kusky, T. M., Chen, Y., and Xiao, Y. (2018). Paleoproterozoic Assembly of the North and South Tarim Terranes: New Insights from Deep
Seismic Profiles and Precambrian Granite Cores. Precambrian Res. 305, 151-165. doi:10.1016/j.precamres.2017.11.015

Yang, W. C., Wang, J. L., Zhong, H. Z., and Chen, B. (2012). Analysis of Regional Magnetic Field and Source Structure in Tarim Basin. Chin. J. Geophys. 55 (4), 1278-1287. doi:10.1002/cjg2.1765

Yichang, W., Hui, Y., Xiaomu, W., and Binqing, Z. (2019). Aklamakan Pre-sinian Paleorift and its Petroleum Potential. Xinjiang Pet. Geology. 15 (3), 191.

Kang, Y. Z. (2004). Targets for Exploration of Giant Oil-Gas Fields in Tarim Basin. Xinjiang Pet. Geology. 25 (6), 581.

Zhang, C.-L., Zou, H.-B., Li, H.-K., and Wang, H.-Y. (2013). Tectonic Framework and Evolution of the Tarim Block in NW China. Gondwana Res. 23 (4), 1306-1315. doi:10.1016/j.gr.2012.05.009

Zhang, J. X., Mattinson, C. G., Yu, S. Y., and Li, Y. S. (2014). Combined RutileZircon Thermometry and U-Pb Geochronology: New Constraints on Early Paleozoic HP/UHT Granulite in the South Altyn Tagh, north Tibet, China. Lithos 200-201, 241-257. doi:10.1016/j.lithos.2014.05.006

Zhang, P. Z., Deng, Q. D., Zhang, Z. Q., and Li, H. B. (2013). Active Faults, Earthquake Hazards and Associated Geodynamic Processes in continental China. Scientia Sinica Terrae 43 (10), 1607-1620.

Zhu, G.-Y., Ren, R., Chen, F.-R., Li, T.-T., and Chen, Y.-Q. (2017). Neoproterozoic Rift Basins and Their Control on the Development of Hydrocarbon Source Rocks in the Tarim Basin, NW China. J. Asian Earth Sci. 150, 63-72. doi:10.1016/j.jseaes.2017.09.018

Conflict of Interest: The authors declare that the research was conducted in the absence of any commercial or financial relationships that could be construed as a potential conflict of interest.

Publisher's Note: All claims expressed in this article are solely those of the authors and do not necessarily represent those of their affiliated organizations, or those of the publisher, the editors and the reviewers. Any product that may be evaluated in this article, or claim that may be made by its manufacturer, is not guaranteed or endorsed by the publisher.

Copyright (c) 2022 Kuang, Zhu, Ning, Li, Zheng, Li and Zhou. This is an open-access article distributed under the terms of the Creative Commons Attribution License (CC $B Y$ ). The use, distribution or reproduction in other forums is permitted, provided the original author(s) and the copyright owner(s) are credited and that the original publication in this journal is cited, in accordance with accepted academic practice. No use, distribution or reproduction is permitted which does not comply with these terms. 